\title{
Pengaruh Lingkungan Kerja Terhadap Kinerja Karyawan PT. Jico Agung Palembang
}

\author{
Ria Purnama Sari, Roswaty \& M. Kurniawan \\ Universitas Indo Global Mandiri \\ Email: rhiapurnamas@gmail.com
}

\begin{abstract}
This study aims to investigate the influence of work environment on the performance of the employees of PT Jico Agung Palembang. Data obtained from 58 respondents consisting of leaders and all employees of PT Jico Agung Palembang. Data were collected through interviews, observations, and questionnaires and analysed using simple linear regression on SPSS. The results reveal that work environment has a positive and significant effect on performance. The relationship between work environment and performance is strong as indicated by the correlation coefficient of $73.5 \%$. The determination test of 0.541 proves that the work environment affects performance by $54.1 \%$ and the remaining $45.9 \%$ is influenced by other variables outside of this study.
\end{abstract}

Keywords: work environment, performance.

\section{Pendahuluan}

Setiap perusahaan di tuntut untuk memiliki manajemen yang baik. Suatu manajemen perusahaan yang baik pasti dapat meningkatkan efektivitas perusahaan. Efektivitas suatu perusahaan dapat tercapai dengan baik sehingga mampu untuk bersaing dengan perusahaan lainnya. Seperti sumber daya manusia yang merupakan salah satu faktor penting dan memiliki peran yang besar dalam suatu perusahaan. Salah satu peran penting yang harus ditekankan oleh suatu perusahaan agar dapat mencapai tujuannya adalah dengan menciptakan lingkungan kerja baik lingkungan kerja secara fisik maupun lingkungan kerja non fisik. Seperti persepsi dari para karyawan mengenai lingkungan kerja yang mereka dapatkan sehingga karyawan dapat memberikan penilaian yang berbeda atas segala aspek dari lingkungan kerja. Apabila persepsi yang ditunjukkan karyawan itu baik maka akan mempengaruhi kinerja karyawan itu baik pula karena dapat membuat para karyawan merasa lebih nyaman dan menyenangkan dengan keadaan lingkungan kerja yang baik sedangkan apabila persepsi yang ditunjukkan karyawan buruk maka kinerja dari karyawan tersebut juga akan berkurang.

Menurut (Luthans, 2011), lingkungan kerja adalah lingkungan di mana karyawan melakukan pekerjaannya sehari-hari. Lingkungan kerja yang kondusif memberikan rasa aman dan memungkinkan para karyawan untuk dapat berkerja optimal. Lingkungan kerja dapat mempengaruhi emosi karyawan. Jika karyawan menyenangi lingkungan kerja di mana dia bekerja, maka karyawan tersebut akan bertahan di tempat kerjanya untuk melakukan aktivitas sehingga waktu kerja dipergunakan secara efektif dan optimas prestasi kerja karyawan juga tinggi. Kinerja pada umumnya diartikan sebagai kesuksesan seseorang didalam melaksanakan suatu pekerjaan. Kinerja karyawan merupakan hasil kerja yang dicapai seseorang dalam melaksanakan tugas-tugas yang dibebankan kepadanya. Kinerja karyawan meliputi kualitas dan kuantitas output serta kendala dalam bekerja dengan baik bila memiliki kinerja yang tinggi sehingga dapat menghasilakan 
kerja yang baik pula. Menurut (Yusuf Palgunanto, Dkk. 2010: 67) Kinerja adalah perilaku nyata yang ditampilkan oleh karyawan dalam melakukan pekerjaan dan hasil kerja karyawan dalam mencapai persyaratan-persyaratan pekerjaan yang diberikan, dengan kata lain kinerja adalah hasil kerja karyawan baik dari segi kualitas maupun kuantitas berdasarkan standar kerja yang telah ditentukan.

PT. Jico Agung merupakan perusahaan yang bergerak di bidang distributor Consumer Gooods yang merupakan bagian dari Miwon Group Indonesia yang saat ini sedang berkembang pesat di Kota Palembang yang beralamat di Jalan. Soekarno Hatta Komplek Pergudangan Polling No.88B, Karya Baru, Alang-Alang Lebar Palembang 30961. Tujuan penelitian ini adalah untuk menganalisis Pengaruh Lingkungan Kerja Terhadap Kinerja Karyawan pada PT. Jico Agung Palembang.

\section{Tinjauan Literatur}

\subsection{Lingkungan Kerja}

Pengertian lingkungan kerja menurut Armstrong dalam Kisworo (2012) the work environment consistof the system of work, the design of jobs, working conditions, and the way sin which people are treated at work by the irmanagers and co-workers. Lingkungan kerja terdiri dari sistem kerja, desain pekerjaan, kondisi kerja, dan cara-cara dimana orang diperlakukan ditempat kerja dengan manajer mereka dan rekan kerja. Menurut Nitisemito dalam Nuraini (2013), adalah segala sesuatu yang ada disekitar pekerja dan dapat mempengaruhi mereka dalam menjalankan tugas-tugas yang dibebankan. Menurut Sedarmayati (2015:1), mendefinisikan lingkungan kerja adalah keseluruhan alat perkakas dan bahan yang dihadapi, lingkungan sekitarnya dimana seseorang bekerja, metode kerjanya, serta pengaturan kerjanya baik, sebagai perseorangan maupun sebagai kelompok.

\subsection{Kinerja Karyawan}

Menurut Prawirosentono (2012) menyebutkan kinerja, atau performance adalah hasil kerja yang dapat dicapai oleh seorang atau sekelompok orang dalam suatu organisasi, sesuai dengan tanggung jawab dan wewenang masing-masing dalam upaya mencapai tujuan organisasi. Terdapat hubungan erat antara kinerja perorangan dengan kinerja organisasi, dengan kata lain, bila kinerja karyawan baik maka kemungkinan kinerja organisasi juga baik. Arifin dkk (2015) menyebutkan kinerja, atau performance adalah hasil kerja yang dapat dicapai oleh seorang atau sekelompok orang dalam suatu organisasi, sesuai dengan tanggung jawab dan wewenang masing-masing dalam upaya mencapai tujuan organisasi.

\section{Metode Penelitian}

Jenis data yang digunakan penulis dalam penelitian di PT. Jico Agung Palembang adalah: Pendekatan yang digunakan dalam penelitian ini dengan menggunakan pendekatan kuantitatif dan di bantu dengan program SPSS, dengan menyebarkan kuisioner kepada karyawan untuk memperoleh data yang akurat. Menurut Sugiyono (2013) teknik pengumpulan data merupakan langkah yang paling strategis dalam penelitian, karena tujuan utama dari penelitian adalah mendapatkan data. Adapun teknik-teknik pengumpulan data sebagai berikut: (1) Wawancara, penulis memilih secara acak responden untuk diwawancarai mengenai penelitian ini, yaitu tentang lingkungan kerja. 
Dari wawancara tersebut penulis mendapatkan beberap hal yang penulis maasukan dan penulis jadikan bahasn untuk kuesioner dalam penelitian ini; (2) Observasi, Selain melakukan wawancara penulis melakukan observasi pada PT. Jico Agung Palembang. Penulis mengamati keadaan lingkungan kerja pada PT tersebut dengan cara berkeliling kantor; (3) Kuesioner, Setelah melakukan wawancara dan observasi kepada beberapa responden dan hasil pengamatan penulis pada di PT. Jico Agung Palembang. Penulis mendapatkan beberapa pertanyaan yang menyangkut lingkungan kerja pada PT. Jico Agung Palembang. Dan Penulis tuangkan kedalam kuesioner penelitian.

Populasi menurut Fauzi, Dencik dan Asiati (2019), adalah "wilayah generalisasi yang terdiri atas: obyek/subyek yang mempunyai kualitas dan karakteristik tertentu yang ditetapkan oleh peneliti untuk dipelajari dan kemudian ditarik kesimpulannya". Populasi dalam penelitian ini adalah karyawan dari PT. Jico Agung Palembang berjumlah 58 orang meliputi pimpinan dan seluruh karyawan. Sampel adalah bagian dari jumlah dan karakteristik yang dimiliki oleh populasi tersebut. Bila populasi besar, dan peneliti tidak mungkin mempelajari semua yang ada pada populasi, misalnya karena keterbatasan dana, tenaga dan waktu, maka peneliti dapat menggunakan sampel yang diambil dari populasi itu hanya 58 orang (Sugiyono, 2017). Teknik analisis menggunakan regresi sederhana.

\section{Hasil dan Pembahasan}

Penelitian ini telah dilakukan dengan menyebarkan 58 kuesioner kepada 58 responden yang terdiri dari karyawan PT. Jico Agung Palembang. Dimana sampel yang digunakan ialah sampel jenuh, yaitu pengambilan sampel keseluruhan. Pengelohan data menggunakan SPSS v.23 maka didapat hasil penelitian sebagai berikut.

Uji validitas dilakukan untuk mengukur tepat atau tidak indikator atau kuesioner dari masing-masing variabel. Pengujian dilakukan dengan membandingkan rhitung dengan rtabel dengan mengunakan program SPSS.

Tabel 1. Variabel Lingkungan Kerja (X)

\begin{tabular}{|l|l|l|l|}
\hline Pertanyaan & rhitung & rtabel & Keterangan \\
\hline P_1 & 0,735 & 0,256 & Valid \\
\hline P_2 & 0,894 & 0,256 & Valid \\
\hline P_3 & 0,933 & 0,256 & Valid \\
\hline P_4 & 1,011 & 0,256 & Valid \\
\hline P_5 & 0,676 & 0,256 & Valid \\
\hline P_6 & 0,493 & 0,256 & Valid \\
\hline P_7 & 0,502 & 0,256 & Valid \\
\hline P_8 & 0,502 & 0,256 & Valid \\
\hline P_9 & 0,503 & 0,256 & Valid \\
\hline P_10 & 0,625 & 0,256 & Valid \\
\hline P_11 & 0,676 & 0,256 & Valid \\
\hline P_12 & 0,493 & 0,256 & Valid \\
\hline P_13 & 0,502 & 0,256 & Valid \\
\hline P_14 & 0,502 & 0,256 & Valid \\
\hline P_15 & 0,503 & 0,256 & Valid \\
\hline P_16 & 0,652 & 0,256 & Valid \\
\hline
\end{tabular}


Tabel 2. Validitas Variabel Kinerja (Y)

\begin{tabular}{|l|l|l|l|}
\hline Pertanyaan & rhitung & rtabel & Keterangan \\
\hline K_1 & 0,569 & 0,256 & Valid \\
\hline K_2 & 0,726 & 0,256 & Valid \\
\hline K_3 & 0,795 & 0,256 & Valid \\
\hline K_4 & 0,812 & 0,256 & Valid \\
\hline K_5 & 1,025 & 0,256 & Valid \\
\hline K_6 & 0,749 & 0,256 & Valid \\
\hline K_7 & 0,503 & 0,256 & Valid \\
\hline K_8 & 0,504 & 0,256 & Valid \\
\hline K_9 & 0,760 & 0,256 & Valid \\
\hline K_10 & 0,812 & 0,256 & Valid \\
\hline
\end{tabular}

Uji reliabilitas digunakan untuk mengetahui apakah indikator atau kuesioner yang digunakan dapat dipercaya dan handal sebagai alat ukur variabel. Reliabilitas diukur dengan uji statistik cronbach'salpha( $\alpha$ ). Suatu variabel dikatakan reliabel jika memberikan nilai cronbach' alpha> 0,60. (Ghozali, 2016)

Tabel 3. Hasil Uji Reliabilitas

\begin{tabular}{|l|l|l|l|}
\hline Variabel & $\begin{array}{l}\text { Cronbach'sAlph } \\
\text { a }\end{array}$ & $\begin{array}{l}\text { Standar } \\
\text { Reabilitas }\end{array}$ & Keterangan \\
\hline LingkunganKerja & 0,893 & 0,60 & Reliabel \\
\hline KinerjaGuru & 0,935 & 0,60 & Reliabel \\
\hline
\end{tabular}

Nilai Cronbach'sAlpha semua variabel lebih besar dari 0,60 sehingga dapat disimpulkan indikator atau kuesioner digunakan variabel lingkungan kerja terhadap kinerja karyawan semua dikatakan reabilitas dan dapat dipercaya sebagai alat ukur variabel.

Uji normalitas digunakan untuk mengetahui apakah populasi data berdistribusi normal atau tidak. Uji ini biasanya digunakan untuk mengukur data berskala ordinal, interval, dan rasio.

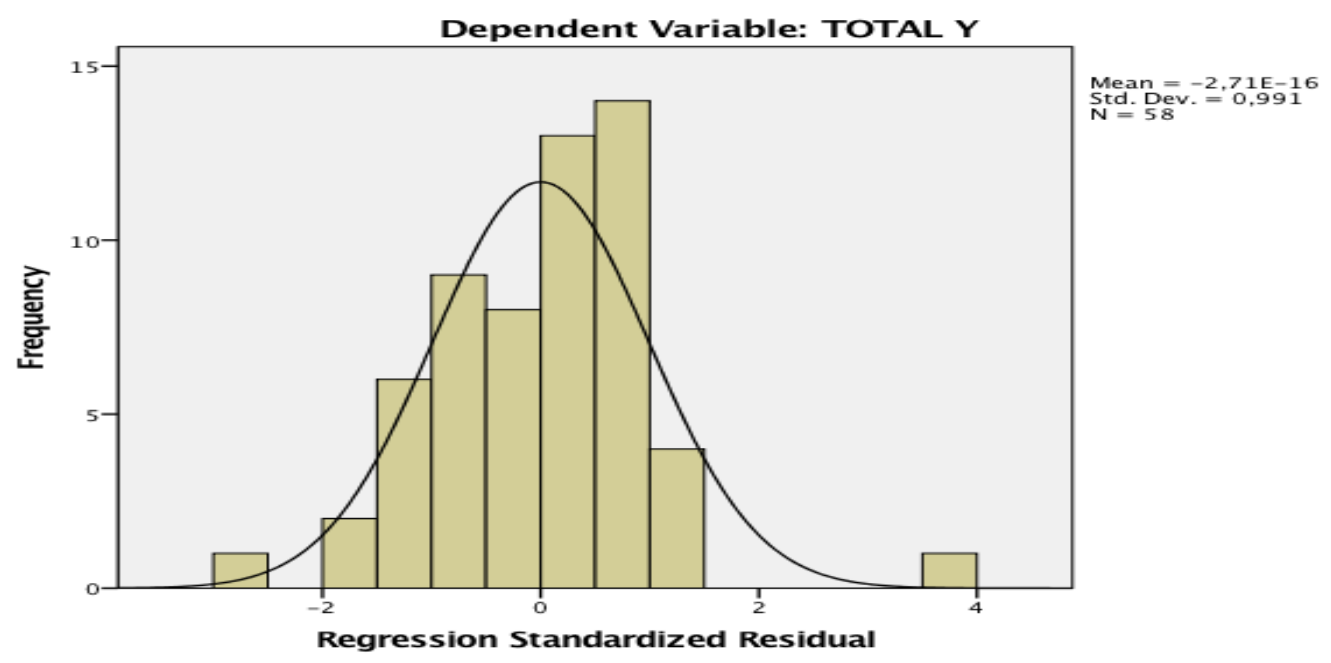

Gambar 1. Hasil Uji Normalitas - Histrogram 
Berdasarkan gambar diatas tampilan grafik normal Plot yang tersaji diatas dapat disimpulkan bahwa grafik histogram memberikan pola distribusi yang normal karena garis diagonalnya mengikuti bentuk kurva seperti terlihat pada gambar diatas yang artinya data berdistribusi normal.

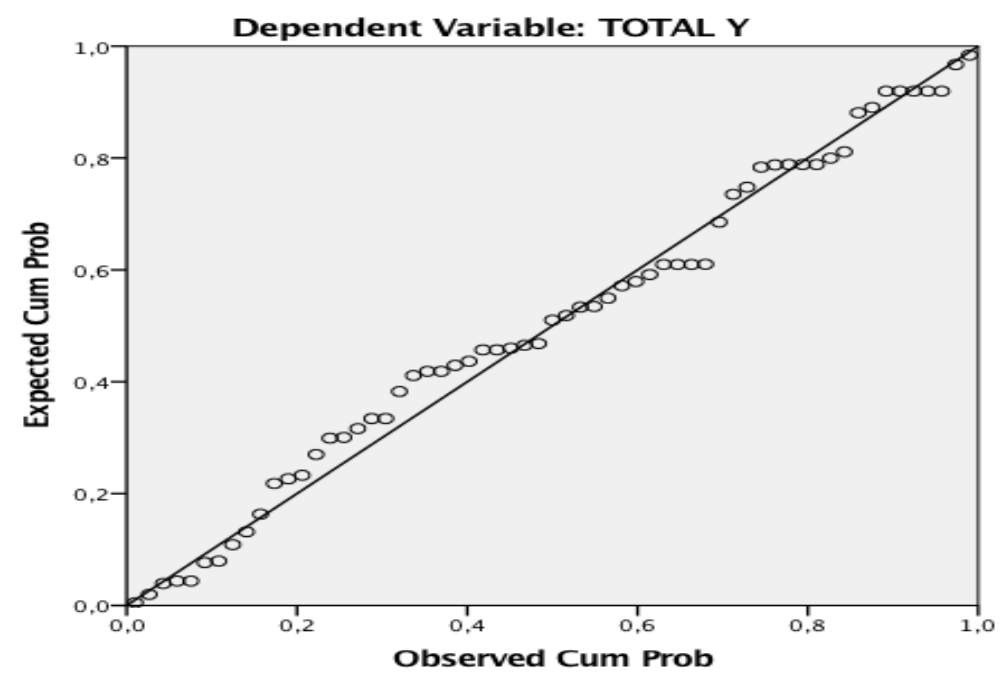

Gambar 2. Hasil Uji Normalitas - P-P Plot

Berdasarkan gambar grafik $P$-P Plot juga menunjukkan kesimpulan, dari tampilan di atas terlihat bahwa ada hanya sedikit data yang menyebar keluar dari garis diagonal, sehingga masih dapat dinyatakan normal.

Penelitian ini menggunakan regresi linear sederhana untuk pembuktian hipotesis penelitian. Analisis ini akan menggunakan input berdasarkan data yang diperoleh dari kuesioner. Hasil pengolahan data dengan menggunakan program SPSS v.23 selengkapnya ada pada lampiran dan selanjutnya diringkas sebagai berikut:

Tabel 4. Uji Regresi Linier Sederhana

\begin{tabular}{|c|c|c|c|c|c|c|c|}
\hline \multirow[b]{2}{*}{ Model } & \multicolumn{2}{|c|}{ UnstandardizedCoefficients } & \multirow{2}{*}{$\begin{array}{l}\text { StandardizedC } \\
\text { oefficients } \\
\text { Beta }\end{array}$} & \multirow[b]{2}{*}{$\mathrm{T}$} & \multirow[b]{2}{*}{ Sig. } & \multicolumn{2}{|c|}{ CollinearityStatistics } \\
\hline & B & Std. Error & & & & Tolerance & VIF \\
\hline $1 \quad$ (Constant) & 3,267 & 4,904 & & 666 &, 508 & & \\
\hline Lingkungan Kerja & .560 &, 069 & .735 & 8,119 &, 000 & 1,000 & 1,000 \\
\hline
\end{tabular}

a. DependentVariable: TOTAL Y

Berdasarkan data tabel 4 dimana hasil analisis regresi diperoleh persamaan regresi sebagai berikut:

$\mathrm{Y}=3,267+0,560 \mathrm{X}$

Hasil analisis regresi linear sederhana yang masih berbentuk angka dapat dijelaskan dalam bahasa yang mudah dipahami sebagai mana berikut ini: Nilai konstanta sebesar 3,267 berarti jika variabel lingkungan kerja bernilai nol, maka kinerja pegawai akan bernilai sebesar 3,267. Sehingga dapat di simpulkan bahwa tanpa ada variabel lingkungan kerja maka kinerja karyawan akan sebesar 3,267 dan menunjukan hasil yang negatif. Hal ini berarti variabel pengembangan karir mempengaruhi kinerja karyawan sebesar 
0,560 atau berpengaruh secara positif yang artinya jika variabel lingkungan kerja meningkat sebesar 1, maka berpengaruh terhadap kinerja karyawan akan meningkat sebesar 0,560 .

Uji ini menunjukan hasil seberapa besar atau ada tidaknya hubungan antar variabel secara parsial terhadap variabel dependent yang berguna untuk membuktikan hipotesis yang diajukan oleh peneliti, berikut disajikan output uji parsial dari variabel lingkungan kerja (X) terhadap variabel dependent Kinerja Karyawan (Y).

Tabel 5. Uji t Lingkungan Kerja

\begin{tabular}{|c|c|c|c|c|c|c|c|}
\hline \multirow[b]{2}{*}{ Model } & \multicolumn{2}{|c|}{ UnstandardizedCoefficients } & \multirow{2}{*}{\begin{tabular}{|l} 
StandardizedC \\
oefficients \\
Beta \\
\end{tabular}} & \multirow[b]{2}{*}{$\mathrm{T}$} & \multirow[b]{2}{*}{ Sig. } & \multicolumn{2}{|c|}{ CollinearityStatistics } \\
\hline & B & Std. Error & & & & Tolerance & VIF \\
\hline $1 \quad$ (Constant) & 3,267 & 4,904 & &, 666 &, 508 & & \\
\hline SUMX &, 560 &, 069 &, 735 & 8,119 & 000 & 1,000 & 1,000 \\
\hline
\end{tabular}

a. DependentVariable: TOTAL Y

Pada tabel diatas diperoleh kesimpulan uji t parsial berdasarkan nilai signifikansi output SPSS. Dasar pengambilan keputusan Uji t Parsial (Regresi Linier Sederhana) berdasarkan nilai hitung dan tabel: Menurut V. Wiratna Sujarweni (2014:155) jika nilai $t_{\text {hitung }}>t_{\text {tabel }}$ maka artinya variable independent $(\mathrm{X})$ secara parsial berpengaruh terhadap variable dependent $(\mathrm{Y})$. Dengan rumus $\mathrm{t}_{\text {tabel }}=(\propto / 2 ; \mathrm{n}-\mathrm{k}-1)=(0,05 / 2 ; 58-1-1)=(0,025 ; 56)=2,003$

Ho: Menunjukkan tidak terdapat pengaruh lingkungan kerja terhadap kinerja karyawan pada PT. Jico Agung Palembang.

$\mathrm{H}_{1}$ : Menunjukkan terdapat pengaruh lingkungan kerja terhadap kinerja karyawan pada PT. Jico Agung Palembang.

Nilai X berpengaruh terhadap Y dikarenakan nilai $\mathrm{X}<0.05$ berpengaruh terhadap $\mathrm{Y}$ dikarenakan $>0,05$ maka konstanta berpengaruh terhadap model regresi. Diketahui nilai Sig. Untuk pengaruh $\mathrm{X}$ terhadap $\mathrm{Y}$ adalah sebesar $0,000<0,05$ dan. Nilai $t_{\text {hitung }} 8,119>$ $t_{\text {tabel }}$ 2,003 sehingga dapat disimpulkan bahwa lingkungan kerja $(X)$ berpengaruh terhadap Kinerja karyawan $(\mathrm{Y})$.

Analisis korelasi (r) digunakan untuk mengukur tinggi rendahnya derajat hubungan antar variabel yang diteliti. Sedangkan Menurut Ghozali (2011), Koefisien determinasi ini digunakan untuk mengetahui seberapa besarnya persentase hubungan variabel independen terhadap variabel dependen. Besarnya persentase pengaruh semua variabel independen terhadap nilai variabel dependen dapat diketahui dari besarnya koefisien determinasi $\left(\mathrm{R}^{2}\right)$ persamaan regresi.

Tabel 6. Hasil Uji Koefisien Korelasi dan Determinasi

\begin{tabular}{|l|l|l|l|l|l|}
\hline Model & & & & & \\
& $\mathrm{R}$ & $\mathrm{R}$ Square & Adjusted R Square & $\begin{array}{l}\text { Std. } \\
\text { ErroroftheEstimate }\end{array}$ & Durbin-Watson \\
\hline 1 &, $735^{\mathrm{a}}$ &, 541 &, 532 & 4,102 & 1,873 \\
\hline
\end{tabular}

a. Predictors: (Constant), SUMX

b. DependentVariable: TOTAL Y 
Tabel diatas menunjukan hasil koefisien korelasi $(\mathrm{R})=0,735 \mathrm{atau} 73,5 \%$. Dari hasil perhitungan tersebut menunjukkan bahwa tingkat keeratan variabel $\mathrm{X}$ kevariabel $\mathrm{Y}$ adalah erat. Dan didapatkan nilai dari R Square ini menandakan bahwa variabel independent (X) berkontribusi terhadap variabel dependent $(\mathrm{Y})$ sebesar 0,541. Yang berarti variabel lingkungan kerja $(\mathrm{X})$ mempengaruhi variabel kinerja $(\mathrm{Y})$ sebesar $54,1 \%$ dan sisanya $45,9 \%$ di pengaruhi oleh variabel lain di luar penelitian ini.

\section{Kesimpulan}

Berdasarkan data yang didapatkan setelah diolah kembali, maka hasil penelitian tentang pengaruh lingkungan kerja terhadap kinerja karyawan pada PT. Jico Agung Palembang dapat ditarik kesimpulan sebagai berikut: (1) Hasil Penelitian dengan menggunakan uji T variabel Lingkungan Kerja menunjukan nilai t hitung $>0,05(0.000>0,05)$ Jadi dapat disimpulkan variabel Lingkungan Kerja (X) berpengaruh Signifikan terhadap Kinerja Karyawan (Y) pada PT. Jico Agung Palembang; (2) Hasil uji dengan menggunakan analisa regresi linier sederhana (b) diperoleh nilai koefisien 0,560 hal ini berarti besarnya kenaikan variabel Lingkungan Kerja (X) sebesar 1 unit dan menyebabkan meningkatnya kinerja karyawan 0,650; (3) Hasil penelitian dengan menggunakan uji Koefisien Korelasi (R) diperoleh nilai 0,735. Hal ini menunjukan hubungan variabel Lingkungan Kerja (X) terhadap Kinerja Karyawan (Y) pada PT. Jico Agung Palembang; (4) Hasil penelitiam menggunakan uji Koefisien determinasi $\left(\mathrm{R}^{2}\right)$ diperoleh nilai sebesar 0,541. Hal ini menunjukkan bahwa $54,1 \%$, sisanya sebesar $45,9 \%$ bisa dijelaskan/dipengaruhi oleh variabel lain yang tidak dimasukan dalam penelitian ini.

Berdasarkan kesimpulan yang telah diperoleh dari hasil penelitian ini, maka ada beberapa saran yang penulis berikan yang berhubungan dengan lingkungan kerja dan kinerja karyawan yaitu antara lain: (1) Pentingnya meningkatkan suasana lingkungan kerja yang baik dalam membantu meningkatkan Kinerja karyawan terutama dalam hal ketersediaan fasilitas di tempat kerja; (2) pentingnya meningkatkan suasana lingkungan kerja yang baik dan kondusif dalam membantu meningkatkan produktivitas karyawan dalam hal suhu udara di tempat kerja, keamanaan dan penerangan perlu adanya pengawasan supaya setiap pekerja merasa aman dan nyaman tanpa merasa terganggu dan khawatir dalam menggunakan peralatan; (3) Diharapkan pihak perusahaan dapat mempertahankan serta meningkatkan pelayanan terhadap lingkungan kerja non fisik, karena variabel lingkungan kerja non fisik mempunyai pengaruh yang dominan dalam mempengaruhi kinerja karyawan, diantaranya yaitu dengan kondisi kerja, fasilitas kerja danhubungan antar karyawan sehingga kinerja karyawan akan terus meningkat.

\section{Referensi}

Afandi Agus, dkk. (2014). Modul ParticipatoryActionResearch. Surabaya: LPPM UIN Sunan Ampel.

Aji, O. A.. \& Budianto, T. (2015). Pengaruh Lingkungan Kerja Terhadap Kinerja Pegawai pada PT Perusahaan Gas Negara (persero) tbk sbu distribusi wilayah 1 jakarta. $3(1)$.

Akbar, R.P.S., \& Usman, H. (2013). Pengantar Statistika. Yogyakarta.

Aksa \& Ririn. (2011). Manajemen Pemasaran Jasa. Bogor: Ghalia Indonesia

Alamaniati, R. (2011). Profil Kreativitas Siswa Dalam Memanfaatkan Limbah Kertas 
Pada Pembelajaran Konsep Daur Ulang Limbah. Skripsi. FP MIPA UPI: Tidak di terbitkan.

Arifin, BS. (2015). Psikologi Sosial. Bandung: CV Pustaka Setia.

Aslinda. (2017). Pengaruh Lingkungan Kerja dan Motivasi Kerja Terhadap Kepuasan Kerja Pegawai Pada Dinas Pekerja Umum Kabupaten Konawe. Program Studi Manajemen Fakultas Ekonomi Dan Bisnis Universitas Halu Oleo Kendari.

Berger, C. R., Roloff, M. E., \& Roskos-Ewoldsen, D. R. (2014). Handbook Ilmu Komunikasi. Bandung: Penerbit Nusa Media.

Damayanti, A. P., Susilaningsih, \& Sumaryati, S. (2013). Pengaruh Kompensasi dan Motivasi Kerja Terhadap Kinerja Karyawan Perusahaan Daerah Air Minum (PDAM) Surakarta. Jupe UNS, 2, pp. 155-168.

Dessler, G. (2011). Manajemen Sumber Daya Manusia. Jakarta: Penerbit Indeks.

Fauzi, F., Dencik, A. B., \& Asiati, D. I. (2019). Metodologi Penelitian Untuk Manajemen dan Akuntansi. Jakarta: Salemba Empat.

Ghozali, I. (2011). Aplikasi Analisis Multivariate Dengan Program SPSS. Semarang: Badan Penerbit Universitas Diponegoro.

Gouzali. S. (2010). Manajemen Sumber Daya Manusia. (Human Resource) Suatu Pendekatan Mikro. Jakarta: Djanbatan.

Hasibuan. (2011). Manajemen Sumber Daya Manusia (Edisi Revi). Jakarta: PT Bumi Aksara. https://journal.stiem.ac.id/index.php/jurman/article/view/158.

Kisworo, B. (2012). Hubungan Antara Motivasi, Disiplin, Dan Lingkungan Kerja Dengan Kinerja Pendidik dan Tenaga Kependidikan Sanggar Kegiatan Belajar Eks Karisidenan Semarang Jawa Tengah. Tesis.UNY.

Luthans, F. (2011). Organizational Behavior: An Evidence Based approach. New York: McGrawHill/Irwin.

Mangkunegara, AP. (2015). Manajemen Sumber Daya Manusia Perusahaan, Bandung : Remaja Rosda Karya.

Nuraini, M., \& Darmawan, D. (2017). Pengaruh Lingkungan Kerja dan Kompetensi Terhadap Kinerja Karyawan PT. Sinar Mas Land Tangerang. Jurnal, 5(3).

Prawirosentono, S. (2008). MSDM Kebijakan Kinerja Karyawan. Yogyakarta: BPFE.

Presilia, \& Octavia, RF. (2010). Analisis pengaruh lingkungan kerja, karakteristik individu, dan motivasi terhadap kinerja pegawai (Kasus: PT. Megatama Plasindo). Jurnal: Bisnis dan Ekonomi, Binus University, DKI Jakarta, Indonesia.

Palgunanto, Y., Suparno, \& Dwityanto, A. (2010). Kinerja Karyawan Ditinjau dari Gaya Kepemimpinan Transformasional. Jurnal Ilmiah Berkala Psikologi, 12(1).

Putra, FR, Utami, Nayati, H., \& Hakam, M.S. (2013). Pengaruh lingkungan kerja terhadap kinerja (Studi pada karyawan PT. Naraya Telematika Malang). Jurnal Administrasi Bisnis, 6(1).

Sedarmayanti. (2015). Manajemen Sumber Daya Manusia. Bandung: PT. Refika 
Aditama.

Setiawan, F., \& Kartika, D. (2014). Pengaruh kompetensi dan lingkungan kerja terhadap kinerja karyawan pada CV. Berkat Anugrah. Ejurnal Manajemen Universitas Udayana, 3(5). https://ojs.unud.ac.id/index.php/Manajemen/article/view/7951

Siagian, S. P. (2014). Manajemen Sumber Daya Manusia. Jakarta: Bumi Aksara.

Sugiyono. (2019). Metodelogi Penelitian Pendidikan. Bandung: Alfabeta.

Sujarweni, V. W. (2014). Metode Penelitian: Lengkap, Praktis, dan Mudah Dipahami. Yogyakarta: Pustaka Baru Press.

Sumidi. (2014). Komunikasi Pribadi Mengenai Penyakit Busuk Batang Pada Rumput Laut. Lampung Selatan. 17 November 2014.

Supriyanto. (2013). Metode Penelitian Sumber Daya Manusia Teori, Kuisioner, Dan Analisis Data. Malang: UIN-Malang Press.

Veithzal. R. (2014). Manajemen Sumber Daya Manusia Perusahaan. Jakarta: PT. Raja Grapindo Persada.

\section{Copyrights}

Copyright for this article is retained by the author(s), with first publication rights granted to the journal.

This is an open-access article distributed under the terms and conditions of the Creative Commons Attribution license (http://creativecommons.org/licenses/by/4.0/) 